\title{
The Idea of Sustainable Development in Reflection on the Meaning of Knowledge and Cognition
}

\section{Idea zrównoważonego rozwoju w namyśle nad znaczeniem wiedzy i poznania}

\author{
Agnieszka Klimska \\ Institute of Philosopy, Cardinal Stefan Wyszynski University in Warsaw, \\ ul. Dewajtis 5, 01-815 Warsaw, Poland \\ E-mail:a.klimska@uksw.edu.pl \\ ORCID: 0000-0002-9115-9492
}

\begin{abstract}
In the case of philosophical justifications of sustainable development it is important to work out epistemological standpoints, adequate to the problems considered in the areas of particular development concepts based on speculative, theoretical knowledge as well as on practical one related to activity and serving its purposes. Epistemology must correlate with the problems that are their material object as well as with goals and cognitive and practical tasks that they (concepts) have to deal with.

The present article makes an attempt at presenting reflection on knowledge and cognition by indicating the epistemological basis of the concept of sustainable development. It will endeavor to draw attention to the need of shaping the attitude of the knowing subject, to facilitate adequate understanding of what we commonly address as sustainability and implementing the proposals of sustainable development and verification of the related sources of cognition.
\end{abstract}

Key words: sustainable development, knowledge, cognition, sustainable development epistemology

\section{Streszczenie}

Dla filozoficznych uzasadnień zrównoważonego rozwoju znaczące jest wypracowywanie stanowisk epistemologicznych, adekwatnych do problemów rozpatrywanych na obszarach poszczególnych koncepcji rozwoju opartych na wiedzy teoretycznej - o charakterze spekulatywnym - i praktycznej, związanej z działaniem i jemu służącej. Epistemologia, będąc częścią każdej z koncepcji rozwoju, powinna korelować z problemami będącymi ich przedmiotem materialnym oraz ze stawianymi przed nimi (koncepcjami) celami i zadaniami poznawczymi i praktycznymi.

Artykuł stanowi próbę ukazania rozważań nad wiedzą i poznaniem poprzez wskazanie epistemologicznych podstaw koncepcji zrównoważonego rozwoju. Celem jest natomiast zwrócenie uwagi na potrzebę ukształtowania właściwego nastawienia podmiotu poznającego, pozwalającego możliwie adekwatnie uchwycić to, co zwykliśmy nazywać zrównoważonym rozwojem, i jednocześnie wdrażającego postulaty zrównoważonego rozwoju, a ponadto weryfikacja związanych z tym źródeł poznania.

Słowa kluczowe: zrównoważony rozwój, wiedza, poznanie, epistemologia zrównoważonego rozwoju

\section{Introduction}

The idea of sustainable development is approached by a number of scientific disciplines, such as, e.g. economics, political science, law, or environmental protection. Its in-depth theoretical analyses resulted in the formulation of various concepts of sustainable development. In the framework of those concepts, scientists present sustainable development proposals that can be implemented in the future. In addition, 
they highlight interrelations and interactions of manifold factors underlying practical implementation of those proposals.

The humanities, including philosophy, make an unquestionable contribution to shaping the theoretical foundations of sustainability. Philosophy provided grounds for elaborating and explaining a number of important issues, both from the methodological and substantive points of view. Among others, it helped to provide semantic solutions which are of crucial significance for researchers dealing with sustainable development as well as to carry out an analysis of categories which are commonly considered contradictory and disparate, such as development versus sustainable. Finally, the issue of sustainable development was discussed with the use of scientific and research instruments from the field of ethics and axiology, or even specialist ecophilosophy.

In the case of philosophical justifications of sustainable development it is important to work out epistemological standpoints, adequate to the problems considered in the areas of particular development concepts based on speculative, theoretical knowledge as well as on practical one related to activity and serving its purposes. Epistemology, as part of each development concept, must correlate with the problems that are their material object as well as with goals and cognitive and practical tasks that they (concepts) have to deal with.

Theoretical knowledge, which provides grounds for theoretical solutions of sustainable development issues, plays a crucial role in providing answers to such questions as, for example, the existence of necessities within the reality, the value of the existing things, the nature of the truth, or other questions related to the limits and possibilities of human cognition, the sources of knowledge, or even to the position of man among other beings. In the context of the above questions, the issue that comes to the fore is a desire to recognize and understand the ultimate causes, i.e. the reasons for the functioning of the world, including the heterogeneous dimensions of human existence, and an analysis of what is and what it is like. Providing answers to the above-outlined questions as well as their constant discovery, or elaboration of new standpoints emerging from the already known views, from our heightened awareness of the assumptions and consequences of specific positions, and finally better understanding of the nature of human endeavors, is supposed to be facilitated by the ongoing progress.

Practical knowledge, which also lies at the basis of the sustainable development concept, supports its neglected aspect of praxis. It is due to the fact that philosophy includes both theory and practice. It has at its disposal tools that can be deemed significant and, moreover, necessary for the development and implementation of sustainable development programs and strategy, and finally, for the management of such a development.
The present article makes an attempt at presenting reflection on knowledge and cognition by indicating the epistemological basis of the concept of sustainable development. At the same time, it is not aimed at making any binding decisions related to selecting cognitive methods in individual concepts. Instead, it will endeavor to draw attention to the need of shaping the attitude of the knowing subject, to facilitate adequate understanding of what we commonly address as sustainability and implementing the proposals of sustainable development and verification of the related sources of cognition.

\section{Towards the epistemology of sustainable de- velopment}

Epistemology deals with the question of truth and validity of man's cognition as an informer in order to discover the ultimate causes for qualifying the value of this cognition. This, in turn, serves the purpose of formulating, in the next stage, the criteria for assessing its actual results and consequences in a critical and non-dogmatic way (Stępień, 2001, p. 6465). Epistemology is also defined as a philosophical inquiry explaining the nature and value of cognition, in other words, it implies analyzing and assessing reliability of information about the reality, reflected in acts of cognition (Krąpiec, 2002, p. 193).

Epistemology, which constitutes a philosophical reflection on cognition, is today more and more often taken into account in scientific solutions provided by researchers from a number of scientific disciplines such as, for example, psychology (Campbell 1989), cultural anthropology (Kapusta, 2007), cognitive science (Żegleń, 2013), or biological science (Creath and Maienschein, 2000). What is more, epistemology can be discussed from different perspectives and contexts, including, for example, information epistemology (Hetmanski, 2013), management epistemology (Sulkowski, 2012), or naturalized epistemology (Miłkowski, 2011). Due to the place and position of epistemology in modern science, or, ultimately, the noticeable transformations that epistemology is undergoing, one can point to the interdisciplinary character of its research on cognition. Following the scientific conception of M. Hetmański, epistemology can thus be described as remaining among or between other cognitive studies that surpass theoretical considerations (Hetmański, 2007, p. 8-9). In this way, a strictly philosophical reflection is opening up to the study of the socio-cultural phenomenon relying in the practical issue of cognizing and evaluation of knowledge.

The idea of sustainable development is an idea of restructuring the world in which boundaries have been surpassed leading to the emergence of non-separate crises, e.g. the environmental crisis, the development crisis, the energy crisis, but of one overall crisis. The crisis, which originates in a failure to adjust human actions to the environment's capacity, resulting in 
adverse changes in the terrestrial systems, including a direct threat to life. According to the World Commission on Environment and Development, this is the status quo of the new reality and there is no escape from it. It is, in turn, necessary to try to understand it and deal with it (WCED, p. 11-13).

The multidimensional character of sustainable development requires conducting a complex epistemological analysis of the idea's assumptions, and thus it requires going far beyond the traditional understanding of epistemology essentially understood as a metatheory of cognition.

The idea of sustainable development needs ordering, clarifying its concepts, defining its cognitive proposals, methods, directions of research and interpretation in the field of social and natural environmental protection, as well as other scientific disciplines whose representatives are involved in the discourse on sustainable development. In this sense, within the sustainable development epistemology, while taking into account the links between natural sciences and humanities together with technical and social sciences, one should reflect on the nature of knowledge that underlies sustainable development, i.e. answer the questions about the source of knowledge, which for the knowing subject consists in information, about the context in which it is communicated, which has a significant impact on its reception. It seems plausible, moreover, to ask about the recipient's experience or to reflect on the cognitive paradigm and the directions of scientific and common thinking, which are being constituted together with the progression of the sustainable development idea. In addition, it is necessary to examine what type of knowledge is addressed by advocates of sustainable development, i.e. whether it has a descriptive, explanatory or justifying character. At the same time, it is worth considering the character of knowledge, so that it could be effectively communicated to the recipient. ${ }^{1}$

Sustainable development epistemology can also be viewed from the perspective of management. Management that should be linked with the idea of sustainable development concerns, on the one hand, managing the process itself, i.e. implementing the theoretical assumptions of sustainable development into social practice. On the other hand, it means managing the organization, administration and strategy in relation to the operation of institutions and bodies responsible for creating and implementing sustainable development programs. Epistemological reflection covering management issues can thus help define cognitive directions of development and solve a dilemma in a situation where a particular way of thinking, related to a specific discipline, ensures an illusion of permanence as regards cognitive issues

\footnotetext{
${ }^{1}$ The author is aware that the posed questions go beyond philosophy, bordering on the sociology of knowledge or the psychology of cognitive processes. The multidimensional character of sustainable development, however,
}

(Sułkowski, 2015, p. 194). It is worth emphasizing that those kinds of cognitive issues often emerge when common research areas are being established within the framework of balancing the levels of sustainable development.

It is difficult to provide unequivocal solutions on strictly epistemological issues within analyses of the idea of sustainable development. However, epistemological issues concerning, among others, the sources of cognition, the impact of experience on the development of knowledge in the area of sustainable development, the role of reason in the process of creating knowledge or the issue of its ambiguity or variability, should not be neglected.

\section{Philosophical reflection on knowledge and cognition in the context of sustainable devel- opment}

The idea of sustainable development assumes adopting a holistic approach to the complex problem of socio-economic growth. A systemic approach to the category of sustainable development should reflect consistent implementation of economic and social goals. Consequently, scientists emphasize, among other things, the importance of applying conjunction in goals and the principle of interrelationships, which points to interconnectedness of all civilizational activities and their products with nature as their carrier, conditioning and ensuring the future of modern society (Jaromi, 2004, p. 158-159). Modern society being a knowledge society constitutes one of the assumed effects of implementing sustainable development proposals. It is supposed to be a society that skillfully uses knowledge in the form of information. It will bring about an increasing quality of the human capital, which will have an impact on the pace of socio-economic development (Polska 2025, p. 13). According to this approach, man is the subject of sustainable development, he is the implementer and recipient of all the effects of cognitive and practical activities following the implementation of individual sustainable development strategies. Finally, he is part of a complicated system and the only entity who can discover in it the previously unseen paradigms and strive to balance its elements.

The anthropocentric character of sustainable development results above all from the place and role of man in creating the civilization of sustainable development, whose existence does not stand in contradiction to the needs of nature (Ab Razak and Sanusi, 2010 , p. 23). The privileged position of man in the environment cannot and should not mean unrestricted transformation of the world. Man as a primary being, free and rational, and constituting an end in itself, should remain subjected to the laws that he

sometimes makes it impediment to adopt a broader approach to the addressed issues, in this case in the field of knowledge and cognition. 
himself creates, but without acting in a manner independent of natural causation. Reason, which directs human activities, or is subjected to it (Krąpiec, 1991, p. 55) manifests itself in conscious decision-making acts. Free action in the external world, i.e. the feature of free agency (Rousseau, 1956, p. 154), is the second argument substantiating human uniqueness among other beings. In the natural world, we do not meet with freedom, but with determinism, while man, having made a free decision, can 'play' on determined natural (social) forces, while pursuing his goals (Krapiec, 2012, p. 310). Implementation of the guidelines for sustainable development should in the first place be an expression of rational and non-accidental human activity, based on knowledge gained in the course of analysis.

Reflection on knowledge and cognition conducted in the context of sustainable development requires differentiating the concepts of cognizing and cognition. The first means activity (activities), while the second the product (products) of these activities, i.e. knowledge, since cognizing does not always end with cognition. Another difficulty lies in assessing the quality of knowledge gained in the cognitive process and in indicating whether it is knowledge in the sense of episteme or doxa. In connection with this, as J. Woleński points out such qualifications as: $\operatorname{cog}$ nitive failure, partial knowledge, superficial knowledge are accepted. The author adopted from A. R. White another important distinction which refers to the following approaches to cognition: cognition as action (activity), as a success, as a performative state, as a disposition, or cognition as an ability (Woleński, 2005, p. 355-360). Due to the heuristic nature of the idea of sustainable development, epistemological reflection on knowledge in the process of cognizing related to, for example, the sources of the ecological crisis, ways to stop the degradation of the natural environment, hunger and poverty, seems to be highly significant. Attainment of goals implies one more important issue, namely, it is important that the theoria knowledge of sustainable development be translated into the sphere of praxis, since the type of cognition determines the effect of human action. Referring to White's suggestion, it might be pointed out that man as the subject of cognition can: act using his cognitive powers, e.g. the reason; achieve a certain mental state, consisting in his being convinced with regard to a given question or having begun to believe in something;

- develop a tendency or ability to gain and possess knowledge.

This differentiation implies the necessity of providing further epistemological solutions, because in the case of information on sustainable development, cognitive success should not consist solely in acquiring specific knowledge by humans, but it is also necessary to carry out qualification of the gained knowledge into episteme and doxa, and take into account the question of discrepancies in cognitive results and succumbing to illusions.

Implementation of sustainable development proposals requires communicating specific knowledge. However, it is worth noticing that, today, the social and natural environment is so variable that information about the surrounding reality is quickly becoming obsolete. At the same time, it is widely emphasized that knowledge is a prerequisite of individual and collective success, and the intellectual climate of development, evidently emphasized in current development strategies, is propagated (Kiwak, 2007 , p. 12). In this context, the question of providing knowledge about the know-how processes gains on importance. Knowledge about facts, such as know-what, i.e. passing on news about events, seems to be insufficient at present. Knowledge about processes enables adaptation of the knowing subject to current conditions, shaping his heuristic thinking skills. This opens up for man a chance to acquire the ability not only to identify problem situations, but also to respond to them in an active way, even to those that generate a sense of cognitive and practical uncertainty.

Sustainable development epistemology should approach man as the subject of cognition, analyze the issues of his cognitive functions, their significance in our lives as well as the role of reason or experience. Thus, it is possible to investigate how the ways of gaining knowledge about the world can be described by means of precise and objective rules, and finally, how lasting they are, by what methods they are achieved and what role they play in human activity and in human experience of the world (Kapusta, 2007, p. 161).

\section{From theoria to praxis of sustainable develop- ment. Skill-related dimension of epistemol- ogy}

Due to the practical context of knowledge, epistemology in its skill-related dimension may focus its reflection on the relationship between theory and practice, and additionally, on the problem of the agency of the idea of sustainable development. In this case, the practicality of theoretical knowledge is evaluated. It seems that the idea of sustainable development clearly implies the proposal of developing theory by solving specific practical problems. Thus, a close relationship between theory and practice is assumed. However, it should be realized that there is no smooth transition from theoria to praxis of sustainable development. Therefore, their mutual interaction requires defining and subsequently acknowledging epistemological differences between them. It is also important to realize the existence of two forms of knowledge - theoretical and practical. Re- 
alization of the fact will allow to take them into account in the cognitive process and using each of them in appropriate situations.

Epistemological reflection may also have an impact on implementing sustainable development programs. Practice requires knowledge, which in the case of sustainable development is provided by theoreticians' scientific output, by researchers dealing with this area of study in the framework of various disciplines. Knowledge about the world, however, includes both common and scientific knowledge. People as thinking and acting beings select and interpret the data about reality. Those data incorporate, for example, scientific facts, but also events that emerge as a result of individual observation or experience. The idea of sustainable development is a concept which sets a strictly defined course of action and shows the objectives of their implementation. It is a multifaceted idea, whose basic assumption is to combine, among others, social, economic and environmental issues. Each of the scientific disciplines addresses in its own specific way the problem of getting to know and describing the reality. What is more, each of them contains their own specific constructs, i.e. sets of abstractions, generalizations, formalizations, or idealizations specific for particular levels of the thinking structure (Schütz, 2006, p. 868). Constructs constituting knowledge, which provides the basis of the theoretical and practical assumptions of sustainable development, must be considered in a context that is coherent with respect to this idea. In this case, the goal of sustainable development epistemology would be to provide tools for the verification of the knowledge inscribed in the context characteristic of a specific scientific discipline.

According to A. Schütz, human condition is biographically determined, which means that people have their own history embracing all the previous experience constituting their knowledge. This situation implies some possibilities for future theoretical or practical actions (Schütz, 2006, p. 871). This individual knowledge has an impact on the system of these actions' significance. Consequently, it seems that the priority task as regards the idea of sustainable development should consists in socializing knowledge. However, this should be a type of knowledge that would not be exposed to the risk of, for example, misinterpretation of facts about the real world, which could be the result of the knowing subject's everyday experience. Interpretation of reality complements the knowledge about global problems of the world, which are the basis for the sustainable development strategy. While the idea itself can be considered as heuristic, since its primary goal is to inspire man to action, programs and strategies of sustainable development should be interpreted as defined algorithms containing proposals for specific tasks. Implementation of individual plans means a transition to the level of episteme in a practical sense.
Practical knowledge will be understood here as the foundation of action resulting from the adopted theoretical project. Action will in turn result in an act materializing the whole process and indicating practical implementation of the assumed plan.

Practice implies also decision-making and choosing from among given possibilities (Gadamer, 2008, p. 41). Our life undergoes constant changes, both quantitative and qualitative, resulting in the emergence of new patterns of thinking, deciding and acting. Without reliable knowledge about, for example, the effects of human action in the environment, or of the living conditions of, for example, inhabitants of the South, people will not understand the validity of remedial and auxiliary actions planned in accordance with the assumptions of sustainable development. Whether a given action is evaluated as a priority, depends on the motives by which the planning individual is inspired. The feature of priority or fundamentality in individual evaluation determines when and in what phases a given action should be implemented in order to achieve the intended goal. The feature of importance, validity indicates the reasons why such an action should be taken. Planning constitutes the first step in a decision making process leading to implementation of a given action. The decision, in turn, is connected with reflection on the righteousness of a given action. This stage may involve some difficulties, especially when such an action does not have an every-day quality. The scale of consequences following undertaking or neglecting a given action for future life is an essential factor influencing human choice. An additional obstacle here are multifaceted dependencies appearing at the point of convergence between the project of action and the decision to take action. That is why, when developing a sustainable development strategy, it is necessary to consider the issue of validity as regards the assessment of planned activities from the perspective of their urgency and importance, including adherence to the principle of rationality at the moment of selecting alternative actions. It is also worth pointing out the potential consequences of not only implementing a planned program, but also of a failure to implement it. This will enable an individual evaluating a given situation to predict the consequences of their future actions. It is particularly important in view of the fact that in the course of developing a plan or strategy, implementation of goals is technically, almost automatically assumed. In addition to communicating knowledge in the form of scientific facts, there is a need for justifications that will motivate people to take action. There is and there always be a difference whether argumentation appeals to our feelings and our ability to be interested in concrete practical goals or cultural forms and content, or to our conscience, when the problem refers to the validity of ethical norms, or finally - to our skills and needs (Weber, 2004, p. 141). Actions undertaken in the course of implementing the postulates of sustainable development, 
can be defined as effective when the goals based on them motivate an individual to undertake or repeat those actions. Reiteration of certain defined activities leads to their routinization in effect of which people begin to evaluate their own activities as important (rationality of values) and urgent (rationality of the goal) (Adamczyk, 2003, p. 20) and implement them in line with the assumptions of the strategy. However, the conviction of the righteousness, and sometimes even the necessity to apply the proposed solutions requires communicating reliable knowledge based on truth, a knowledge which is often hard to be propagated in the conditions of socially established doxa.

\section{Conclusion}

Sustainable development can find its practical expression, as long as the person involved in its implementation consciously and willingly decides to adopt a knowledge-based vision of the world, which requires certain sacrifices, changes in attitudes and ways of behavior and is associated with respecting a specific catalog of values. Striving for this vision requires providing theoretical knowledge along with information about its practical consequences. Nowadays, knowledge has become a socio-cultural phenomenon, the goal of practical and cognitive procedures and evaluations (Hetman, 2007, p. 9) of man. For this reason, and because of the multi-contextuality of knowledge, epistemological reflections that underlie sustainable development should be considered important from the point of view of the human being as a cognitive and then acting subject. The direction of these reflections should include the issue of ordering concepts, analysis of definitions and assumptions of sustainable development, bearing in mind the possibility of emerging discrepancies in cognitive results. It would also involve developing the idea itself by formulating cognitive proposals, enriching concepts and sources of knowledge, and also considering the practical dimension of learning and valuing knowledge in the field of sustainable development. Due to the heuristic and interdisciplinary character of the idea, this reflection should concentrate on its cognitive foundations, conducted not only from the perspective of philosophy, but also from the standpoint of other scientific disciplines.

\section{References}

1. AB RAZAK R. R., SANUSI Z. A., 2010, The concept of sustainable development in human civilisation: an introspective view, in: Kemanusiaan, 17, p. 19-36.

2. ADAMCZYK G., 2003, Wartości społeczne w świadomości młodzieży niemieckiej i polskiej KUL, Lublin.

3. AGGESTAM M., 2003, Re-thinking knowledge management: managing communication, in: Creating Knowledge-Based Economy, eds. Gasparski W., Dąbrowski J., Leon Koźmiński Academy of Etrepreneurship and Management, Warsaw, p. 33-49.
4. CAMPBELL D. T., 1989, Fragments of the fragile history of psychological epistemology and theory of science, in: Psychology of science. Contributions to metascience, ed. Gholson B. et al., Cambridge University Press, Cambridge, p. 21-46.

5. CREATH R., MAIENSCHEIN J., 2000, Biology and Epistemology, Cambridge University Press, Cambridge.

6. GADAMER H. G., 2008, Teoria, etyka, edukacja, Uniwersytet Warszawski, Warsaw.

7. HETMAŃSKI M., 2013, Epistemologia informacji, Copernicus Center Press, Cracow.

8. HETMAŃSKI M., 2007, Epistemologia jako filozoficzna refleksja nad poznaniem i wiedzą, in: Epistemologia współcześnie, ed. Hetmański M., TAiWPN Universitas, Cracow, p. 7-6

9. JAROMI S., 2004, Ecologia humana - chrześcijańska odpowiedź na kryzys ekologiczny, in: Bratni Zew, Cracow.

10. KAPUSTA A., 2007, Teoria poznania a nauki o człowieku, in: Epistemologia wspótcześnie, ed. Hetmański M., TAiWPN Universitas, Cracow, p. 161-191.

11. KRAPIEC M. A., 2012, Wprowadzenie do filozofii, KUL, Lublin, p. 269-334.

12. KRĄPIEC M. A., 2002, Epistemologia, in: $P o-$ wszechna Encyklopedia Filozofii, Polskie Towarzystwo Tomasza z Akwinu, Lublin, p. 193-200.

13. KRĄPIEC M. A., 1991, U podstaw rozumienia kultury, KUL, Lublin.

14. MIŁKOWSKI M., 2013, Epistemologia znaturalizowana, in: Przewodnik po epistemologii, ed. Ziemińska R., WAM, Cracow, p. 495-524.

15. PAKSZYS E., 2007, Po co komu partykularyzm teoriopoznawczy? O przeznaczeniu epistemologii feministycznej, in: Epistemologia współcześnie, ed. Hetmański M., TAiWPN Universitas, Cracow, p. 331350.

16. Polska 2025 - Dlugookresowa Strategia Trwatego $i$ Zrównoważonego Rozwoju, 2000, Rządowe Centrum Studiów Strategicznych i Ministerstwo Środowiska, Warsaw.

17. POSKROBKO B., 2011, Wiedza i gospodarka oparta na wiedzy, in: Gospodarka oparta na wiedzy, ed. Poskrobko B., Wydawnictwo Wyższej Szkoły Ekonomicznej, Białystok, p. 25-54.

18. ROUSSEAU J. J., 1956, Trzy rozprawy z filozofii społecznej, PWN. Warsaw.

19. SCHÜTZ A., 2006, Potoczna i naukowa interpretacja ludzkiego działania, in: Współczesne teorie socjologiczne, eds. Jasińska-Kania A., Nijakowski L.M., Szacki J. M., Ziółkowski J.M., (Ed.), Scholar, Warsaw, p. 867-893.

20. STĘPIEŃ A. B., 2001, Wstęp do filozofii, Towarzystwo Naukowe KUL, Lublin.

21. SUŁKOWSKI Ł., 2015, Epistemologia zarządzania humanistycznego, in:. Sprawniejsze państwo, ed. Kierżun W., Poltext, Warsaw, p. 193-207.

22. WCED (World Commission on Environment and Development), 1987, Our Common Future, Oxford Universisty Press, Oxford.

23. WEBER M., 2004, Racjonalność, władza, odczarowanie, Wydawnictwo Poznańskie, Poznań.

24. WOLEŃSKI J., 2005, Epistemologia, PWN, Warsaw.

25. ZACHER L., 2009, Bariery racjonalności w decyzjach (refleksje o kontekstach decydowania), in: Człowiek i jego decyzje, eds. Kłosiński A., Biela A., KUL, Lublin, p. 107-123.

26. ŻEGLEŃ U., 2013, Epistemologia a kognitywistyka, in: Przewodnik po epistemologii, ed. Ziemińska R., WAM, Cracow, p. 457-494. 